\title{
Isolation and characterization of antagonistic bacteria against Vibrio harveyi from milkfish Chanos chanos
}

\author{
KISHORE K. KRISHNANI ${ }^{1,2}$, V. KATHIRAVAN ${ }^{1,3}$, M. KAILASAM ${ }^{1}$, A. NAGAVEL ${ }^{1}$ \\ AND A. G. PONNIAH ${ }^{1}$ \\ ${ }^{1}$ ICAR-Central Institute of Brackishwater Aquaculture, R. A. Puram, Chennai - 600 028, Tamil Nadu, India \\ ${ }^{2}$ National Institute of Abiotic Stress Management, Baramati, Pune - 413 115, Maharashtra, India \\ ${ }^{3}$ Artis Animal Health Care Pvt. Ltd., Surat, Gujarat, India \\ e-mail:krishnanik@hotmail.com
}

\begin{abstract}
Vibrio species are the most dominant multidrug-resistant opportunistic bacterial pathogens in coastal aquaculture environments. There is an urgent need for biocontrol strategy to enhance commercially viable shrimp production. In the present study, eight strains of Bacillus were isolated and characterised from surface mucus of milk fish maintained in greenwater system and their antagonistic effects were evaluated against shrimp pathogenic bacteria Vibrio harveyi, by agar well diffusion and co-culture methods. Promising organisms were immobilised onto a matrix for preparation of bioaugmentor and again tested for antagonistic activity against $V$. harveyi.
\end{abstract}

Keywords: Bioagumentation, Brackishwater aquaculture, Probiotics, Shrimp, Vibrio harveyi

Emerging major constraints in coastal shrimp farming around the world are problems linked to deterioration of pond water quality and stress associated disease incidence. Vibrio species are the predominant bacterial pathogens in the marine environment, causing vibriosis especially in farmed shrimp (Kang et al., 2014). Among them, particularly, Vibrio harveyi is identified as a major pathogen, which is a luminous Gram negative bacterium associated with vibriosis in penaeid shrimp (Moriarty, 1999; Moreno et al., 2017). In addition, there have been several reports indicating the antibiotic resistance of $V$. harveyi, causing mortalities among larvae, post-larvae and cultured shrimp leading to economic losses (Stalin and Srinivasan, 2016; Moreno et al., 2017).

Vibrio spp. are difficult to be controlled in aquaculture and related aquatic environment when the stocking density is high. Antagonistic activity of probiotic bacteria against pathogenic bacteria have been evaluated (Pan et al., 2008; Fjellheim et al., 2010). Reports on isolation, purification and structural elucidation of active compounds from pharmacologically promising marine organisms associated bacteria from Indian marine waters are scanty (Anand et al., 2006; Krishnani, 2010). There is a huge potential for venturing into the micro niche to explore the potential of the bacterial diversity associated with marine organisms as a source of novel biomolecules. Recent developments in molecular biology based techniques have led to rapid and accurate strategies for monitoring, discovery and identification of novel bacteria (Anand et al., 2006; Krishnani et al., 2009; 2010; Krishnani and Kathiravan, 2010), which can be helpful to understand the interaction of marine bacteria. The research findings of Stalin and Srinivasan (2016) are helpful in understanding the multiple antibiotics resistance of $V$. harveyi, which indicated the urgent need for targeted alternative biocontrol strategies to enhance the prospects of commercially viable shrimp cultivation. In the present study, promising antagonistic bacteria have been isolated from surface mucus of fish maintained in greenwater system for controlling pathogenic $V$. harveyi.

Bacterial strains were isolated from the surface mucus of milk fish maintained in greenwater system in coastal aquaculture pond. In brief, about $0.1 \mathrm{~g}$ milkfish slime (mucus from fish surface) was incubated in $10 \mathrm{ml}$ of sterile seawater. After serial dilution, the mixture was inoculated on tryptic soy agar (TSA) by spread plate method and incubated at $28^{\circ} \mathrm{C}$ until visible colonies were formed. Bacterial colonies were further purified and the isolates were initially characterised using standard biochemical tests and later employing molecular techniques.

Couple of isolates were cultured on tryptic soy agar medium (TSA ) at $28^{\circ} \mathrm{C}$ for 48 to $72 \mathrm{~h}$. The cells were harvested from the plates by scraping with a sterile loop and used for fatty acid methyl ester (FAME) analysis. Saponification, methylation and extraction were performed using the procedure described in the MIDI 
manual (Microbial Identification, Inc.) (Sasser, 1990). Cluster analysis was performed using an in-house cluster program and the MIDI software. Sherlock MIS uses fatty acids 9-20 carbons in length. The peaks are automatically named and quantitated by the system.

Genomic DNA was extracted from pure cultures using a DNA isolation kit (Himedia, India) according to the manufacturer's instructions. The bacterial 16S rRNA gene was amplified using universal primers. The PCR thermal program was followed as previously described (Kathiravan and Krishnani, 2013). The sequences were analysed using ABI3100 Genetic Analyser. The sequences obtained were analysed for bacterial species identification using BLASTN programme of NCBI (Altschul et al., 1990). Phylogenetic tree was constructed using the neighbor-joining method from MEGA 4 program package (Tamura et al., 2007).

The antibacterial activity of isolated strains was assessed against two pathogenic bacterial strains viz., $V$. harveyi strain $\mathrm{A} 1$ and $V$. harveyi strain $\mathrm{B} 5$, which were isolated from coastal hatchery using special $V$. harveyi medium (Lachlan et al., 1996). These bacteria were selected after confirming pathogenicity based on the PCR amplification of hemolysin $v h h$ gene. Originally designed primers (Conejero and Hedreyda, 2004) (forward: 5-CTTCACGCTTGATGGCTACTG-3 and reverse: 5-GTCACCCAATGCTACGACCT-3) were used for amplification of $235 \mathrm{bp}$ fragment of hemolysin $v h h$ gene. Pure cultures of the pathogenic strains were inoculated in trypticase soy broth (TSB) and incubated at $28^{\circ} \mathrm{C}$. After $24 \mathrm{~h}$ of incubation, bacterial suspension (inoculum) was diluted with sterile physiological saline, to get a cell density of $10^{8} \mathrm{cfu} \mathrm{ml}^{-1}$.

Bacterial strains isolated from the fish slime were evaluated for their antagonistic activity against the two pathogenic strains of $V$. harveyi using agar well diffusion method. The isolated strains were inoculated into $5 \mathrm{ml}$ of TSB and then incubated at $28^{\circ} \mathrm{C}$. Bacterial suspensions of the two pathogenic strains of $V$. harveyi strains were uniformly spread on TSA plates using sterile cotton swab. The plates having wells of $6 \mathrm{~mm}$ dia were filled with $50 \mu \mathrm{l}$ inoculum of the test strains. The plates were then incubated for $24 \mathrm{~h}$ under aerobic conditions. Inhibition zones of the bacterial growth around the wells were measured in $\mathrm{mm}$. All tests were performed in duplicates.

Co-culture of the test strains along with the pathogenic bacteria was also employed to determine the antagonistic activity of the isolated bacterial strains. Promising antagonistic strains were immobilised onto a matrix (sterile tapioca flour) for preparation of antagonistic bioaugmentor. One hundred microliter each of the bacterial strains was mixed with $500 \mathrm{ml}$ of TS broth containing $10 \mathrm{~g}$ sterilised tapioca flour and incubated for $48 \mathrm{~h}$ at $28^{\circ} \mathrm{C}$ on a rotary shaker $(100 \mathrm{rpm})$. The mixture was centrifuged for $15 \mathrm{~min}$ at $10,000 \mathrm{rpm}$, then washed with sterile phosphate buffered saline (PBS) $(>5 \mathrm{ml})$ to remove the loosely attached cells. The mixture was dried at $40^{\circ} \mathrm{C}$ for $3 \mathrm{~h}$ and stored at $4^{\circ} \mathrm{C}$, until use.

Viability of the antagosistic bacteria in the bioaugmentor was checked for a period of 8 months. For this, known quantity of matrix was taken soon after the immobilisation process and thereafter at monthly intervals into sterile centrifuge tubes containing known volume of sterile PBS. The biofilm cells were dislodged using vortex and then serially diluted and plated onto the suitable agar media (TSA) for determining the total viable count.

Antagonistic effect of bioaugmentor was tested and revalidated against $V$. harveyi using co-culture method. Each of the immobilised strain was added in $25 \mathrm{ml}$ of TSB in a conical flask which was inoculated with the pathogenic strain of $V$. harveyi $\left(10^{6}\right.$ cells $)$. Control broth inoculated with $V$. harveyi, without antagonistic bacterial isolate was also prepared. The co-cultures, made in duplicates were incubated at $28^{\circ} \mathrm{C}$ and samples were taken at an interval of $24 \mathrm{~h}$ for 72 hours for enumeration of Vibrio count on $V$. harveyi medium (Lachlan et al., 1996). Based on the dilution used in the plating, the concentration of the residual amount of viable cells per milliliter at different time intervals were calculated. The reduction percentage of the bacteria was estimated using the following equation:

Reduction percentage $(\mathrm{R} \%)=$ Bacterial cell density in control - Bacterial cell density in in co-culture / Bacterial cell density in control $\times 100$

Eight bacterial isolates designated as DBTGSB1, DBTS12B2, DBTS18B3, DBTS34B4, DBTS21B5, DBTS29B6, DBTS3B7 and DBTS11B8 were isolated from the surface mucus of milk fish maintained in greenwater system in coastal aquaculture ponds. DBTGSB1, DBTS21B5 and DBTS29B6 were positive for oxidase, catalase, voges-proskauer (VP) and negative for gelatinase, indole production and citrate utilisation. DBTS12B2 and DBTS11B8 were positive for oxidase, catalase, indole, VP, gelatin test and negative for methyl red (MR) test. DBTS18B3 and DBTS34B4 were negative for MR test and positive for oxidase, catalase, indole, VP and gelatin hydrolysis tests. DBTS3B7 was positive for catalase and gelatinase; while negative for oxidase, MR-VP and indole (Table 1).

The fatty acid profiles of two promising antagonistic bacterial strains viz., DBTS29B6 and DBT S12B2 
obtained from FAME analysis, confirmed the identity of the strains as Bacillus pumilus and Bacillus subtilis respectively (Fig. 1).

The eight bacterial strains were also identified based on 16S rRNA gene sequence analysis, using BLASTN, based on maximum sequence similarity to species in the NCBI database. 16S rRNA sequences of the eight Bacillus strains were submitted in NCBI-GenBank with accession nos. as given in Table 1. Phylogenetic tree was constructed based on 16S rRNA gene sequence using MEGA 4 (Fig. 2).

V. harveyi strain A1 (Accession No. JF264472) and $V$. harveyi strain B5 (Accession No. JF264473) isolated from coastal hatchery using $V$. harveyi medium were used as test bacteria. The pathogenicity of both the strains were confirmed by amplification and sequencing of the hemolysin (vhh) gene (Fig. 3). The functional gene sequences of $v h h$ gene of $V$. harveyi strain $\mathrm{B} 5$ and $\mathrm{A} 1$

Table 1. GenBank accession numbers of 16S rRNA gene and percentage of similarity

\begin{tabular}{|c|c|c|c|}
\hline $\begin{array}{l}\text { Isolate and GenBank } \\
\text { Acc No. }\end{array}$ & Biochemical test & $\begin{array}{l}\text { 16S rRNA matching \% } \\
\& \text { Accession No. }\end{array}$ & Bacteria \\
\hline DBTGSB1 \& KF860867 & $\begin{array}{l}\text { Indole -ve and +ve for oxidase, catalase, } \\
\text { MR, VP, gelatin hydrolysis }\end{array}$ & $96 \&$ KC250164 & Bacillus pumilus \\
\hline DBTS12B2 \& KF860868 & $\begin{array}{l}\text { +ve for oxidase, catalase, indole, VP, gelatin } \\
\text { and -ve for MR. }\end{array}$ & $97 \&$ JX102497 & Bacillus subtilis \\
\hline DBTS18B3 \& KF860869 & $\begin{array}{l}\text {-ve for MR and +ve for oxidase, catalase, } \\
\text { indole, VP, gelatin hydrolysis }\end{array}$ & $99 \&$ JX901378 & Bacillus licheniformis \\
\hline DBTS34B4 \& KF860870 & $\begin{array}{l}\text {-ve for MR and +ve for oxidase, catalase, } \\
\text { indole, VP, gelatin hydrolysis }\end{array}$ & $99 \&$ JX901378 & Bacillus licheniformis \\
\hline $\begin{array}{l}\text { DBTS21B5 } \\
\& \text { KF860871 }\end{array}$ & $\begin{array}{l}\text {-ve for indole and +ve for oxidase, catalase, } \\
\text { MR, VP, gelatin hydrolysis }\end{array}$ & 99 \& JX841107 & Bacillus pumilus \\
\hline DBTS29B6 \& KF860872 & $\begin{array}{l}\text {-ve for indole and +ve for oxidase, catalase, } \\
\text { MR, VP, gelatin hydrolysis }\end{array}$ & 99 \& AB741462 & Bacillus pumilus \\
\hline DBTS3B7 \& KF860873 & $\begin{array}{l}\text { Catalase, gelatin +ve; Oxidase, MR-VP, } \\
\text { indole -ve }\end{array}$ & $99 \&$ KC329822 & Bacillus megaterium \\
\hline DBTS11B8 \& KF860874 & $\begin{array}{l}\text { +ve for oxidase, catalase, indole, VP, gelatin } \\
\text { and -ve for MR test. }\end{array}$ & 98 \& GU193980 & Bacillus subtilis \\
\hline
\end{tabular}

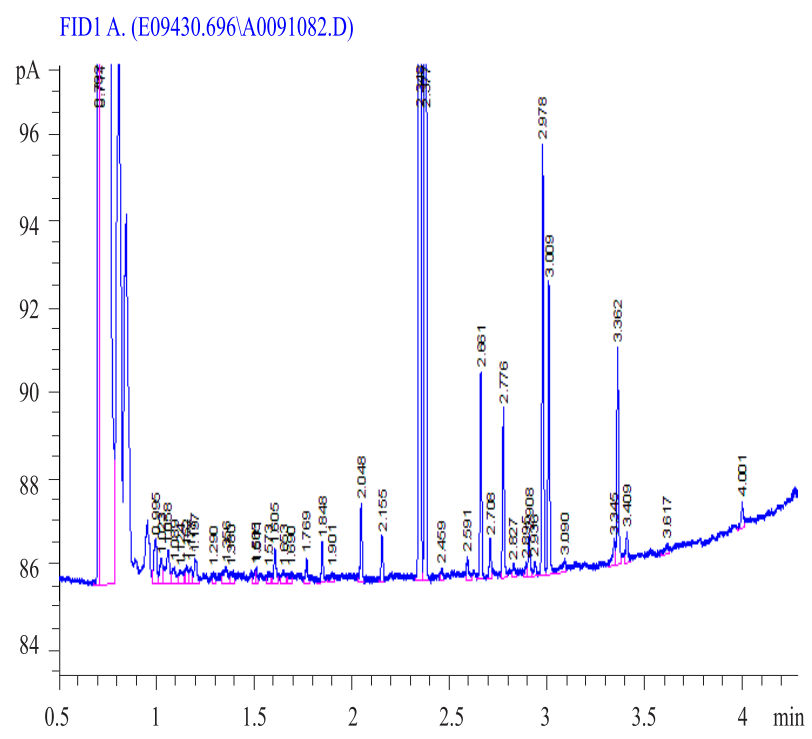

(a)

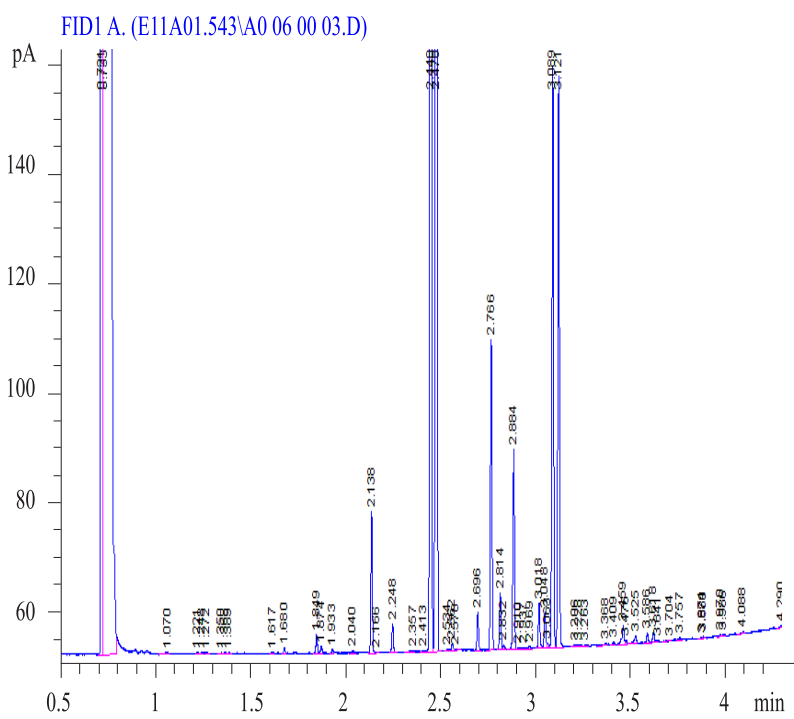

(b)

Fig. 1. FAME analysis of a couple of antagonistic bacterial isolates (a) Bacillus pumilus DBTS29B6 and (b) Bacillus subtilis DBTS12B2 


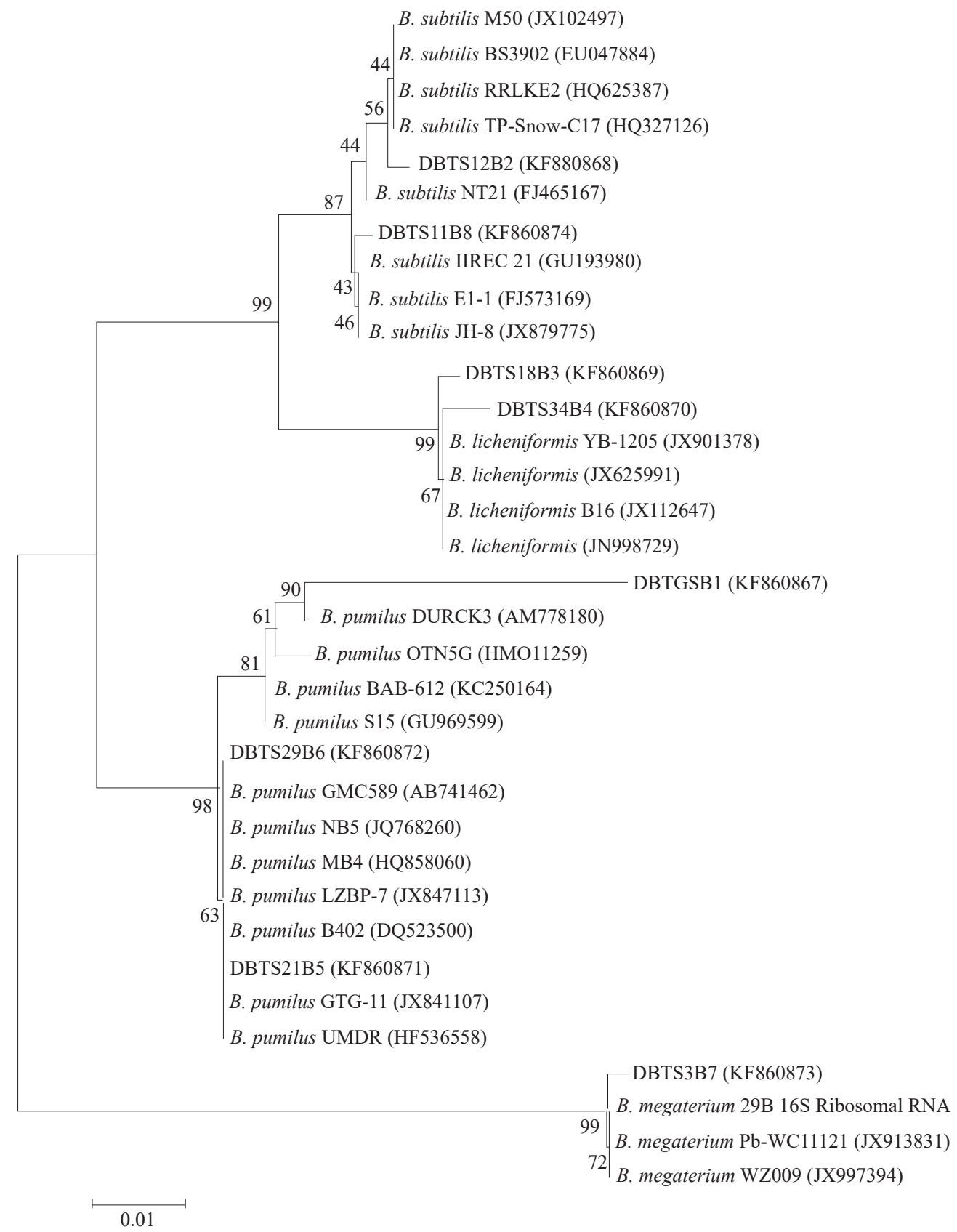

Fig. 2. Phylogenetic tree based on 16S rRNA gene as determined by maximum likelihood method

were also submitted in the GenBank and their accession numbers are KJ000877 and KJ000878 respectively. The pathogenic bacteria were inhibited by antagonistic strains as evidenced by the production of clear zones of inhibition against the growth of the target pathogens. All Bacillus isolates were found most effective against $V$. harveyi strain A1 as compared to $V$. harveyi strain B5 as they yielded 3-16 mm zones of inhibition. Strong inhibition zone of 16 mm against $V$. harveyi strain $\mathrm{A} 1$ was obtained for $B$. subtilis strain DBTS12B2 and B. pumilus strain DBTS29B6. B. licheniformis strains DBTS18B3 and DBTS34B4 showed moderate activity against target pathogens.

Cell viability during storage of the bioaugmentor matrix showed that initial viable bacterial counts in the immobilised matrix was $10^{8}-10^{9}$ cells per $\mathrm{g}$. It was also found that the matrix can retain $10^{8}-10^{9}$ viable cells per $g$ for the first three months of storage at room temperature and thereafter $10^{7}-10^{8}$ viable cells per g during 4-6 months 


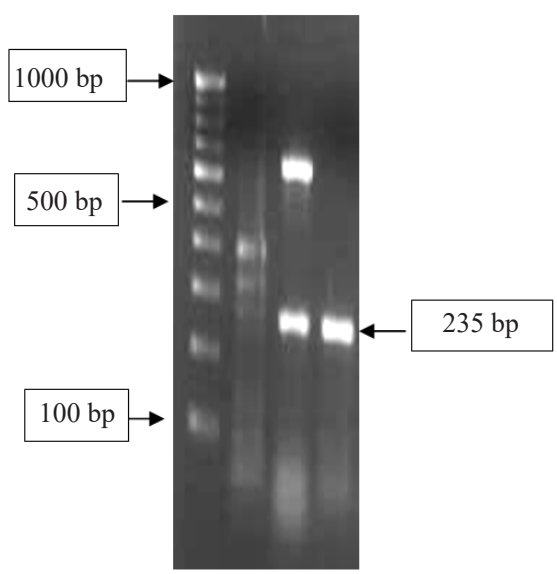

Fig. 3. PCR amplification of $V h h$ gene in $V$. harveyi strain

and $10^{6}-10^{7}$ cells per g during 6-8 months of the storage at room temperature. The potential advantages of tapioca powder as immobilising matrix are: longer shelf life at room temperature, low cost, easy availability, adequate substrate concentration, excellent viable cell loading capacity/storage, high surface area for maintenance of a high microbial cell density and optimisation of microbial growth, easily biodegradable and no residue problem and longer biomass retention time. In the co-culture experiment, immobilised Bacillus strains effectively controlled $V$. harveyi as evidenced from the reduction of 40.54 to $88.65 \%, 60$ to $98.86 \%$ and 73.33 to $99.99 \%$ in 24,48 and 72 h respectively (Fig. 4).

There was no growth on $V$. harveyi agar after $72 \mathrm{~h}$ from $B$. subtilis strain DBTS12B2, B. pumilus strain DBTS29B6 and B. licheniformis strain DBTS4B4 flasks

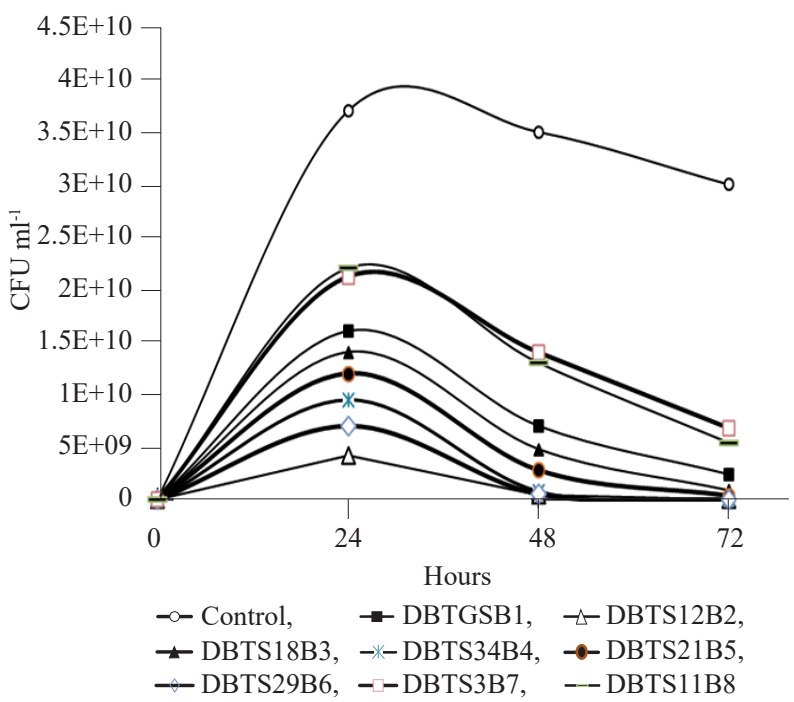

Fig. 4. Changes in residual amount of $V$. harveyi strain A1 with eight strains of Bacillus spp. using co-culture method
(Fig. 4). Almost 99\% reduction of $V$. harveyi strain A1 was noticed. B. megaterium strain DBTS3B7 and B. subtilis strain DBTS11B8 showed moderate reduction (73-82\%) as compared to other isolates.

Fig. 5 shows the inhibitory activity of crude extracts from isolated bacterial strains. B. pumilus strain DBTS29B6 and B. subtilis strain DBTS12B2 showed highest activity against both pathogenic Vibrio species. They have shown considerably higher zone of inhibition against $V$. harveyi strain $\mathrm{A} 1$ (15-16 $\mathrm{mm})$ and $V$. harveyi strain B5 (4-6 mm). B. licheniformis strains DBTS18B3 and DBTS34B4 showed moderate activity against the pathogens.

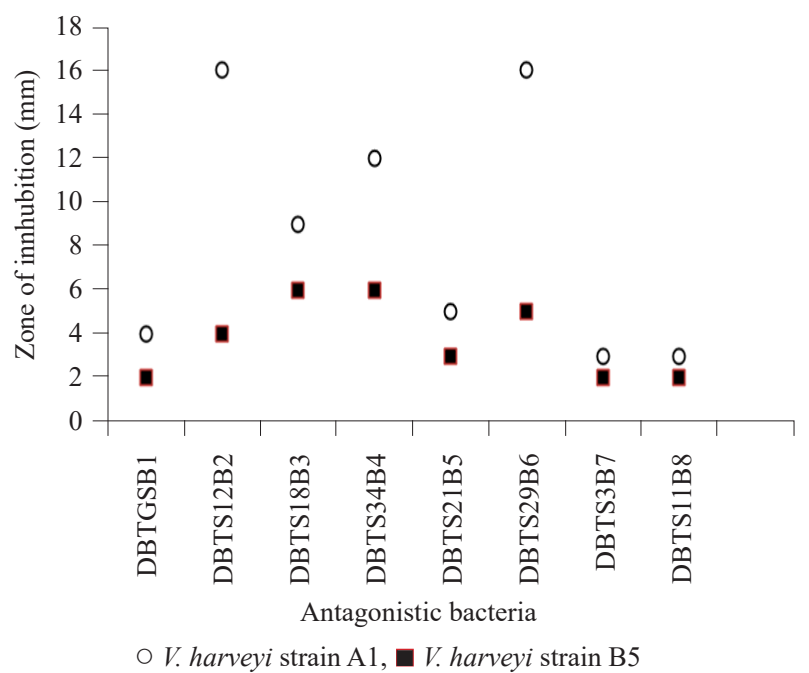

Fig. 5. Results of antagonism assay from well-diffusion method that produced clear zones of inhibition against $V$. harveyi strains A1 and B5

Beneficial bacteria associated with fish slime helps condition the water by inhibiting the growth of Vibrio spp.. Bacillus spp. especially Bacillus subtilis and $B$. licheniformis are widely present in the aquatic environment and are commonly used as probiotic strains against disease causing organisms due to their ability to grow in different conditions (Moriarty, 1999; Decamp, 2004). Control of pathogenic bacteria is effected through a variety of mechanisms such as competitive exclusion, improvement of water quality (Garriques and Arevalo, 1995), enhancement of immune response of host species (Andlid et al., 1995) as well as enhancement of nutrition of host species (Garriques and Arevalo 1995).

Pathogenic Vibrio spp. especially the luminous $V$. harveyi often adversely affects aquaculture production. In the present investigation, eight strains of beneficial Bacillus spp. isolated from fish slime were found 
effective in inhibiting the growth of pathogenic Vibrio harveyi Antagonistic bacterial formulation producing biomolecules with antibacterial activity could be effectively used against pathogenic bacteria in aquaculture and related aquatic environment.

\section{References}

Altschul, S. F., Gish, W., Miller, W., Myers, E. W. and Lipman, D. J. 1990. Basic local alignment search tool. J. Mol. Biol., 215: 403-410. DOI: 10.1016/S0022-2836(05)80360-2.

Anand, T. P., Bhat, A. W., Shouche, Y. S., Roy, U., Siddharth, J. and Sarma, S. P. 2006. Antimicrobial activity of marine bacteria associated with sponges. Microbiol. Res., 161: 252-262. DOI: 10.1016/j.micres.2005.09.002.

Andlid, T., Vazquez-Juarez, R. V. and Gustafsson, L. 1995. Yeast colonising the intestine of rainbow trout (Salmo gairdneri) and turbot (Scophthalmus maximus). Microb. Ecol., 30: 321-334. doi: 10.1007/BF00171938.

Baliao, D. D. 2000. Environment-friendly schemes in intensive shrimp farming. State of the art Series. South-East Asian Fisheries Development Centre, Ilo-ilo, Philippines.

Baliao, D. D., De Los Santo, M. A. and Franco, N. M. 1999. Milkfish pond culture. Aquaculture. extension manual No. 25. South-East Asian Fisheries Development Centre, Ilo-ilo, Philippines.

Conejero, M. J. U. and Hedreyda, C. T. 2004. PCR detection of hemolysin (vhh) gene in Vibrio harveyi. J. Gen. Appl. Microbiol., 50: 137-142.

Decamp, O. 2004. Probiotics in aquaculture: A commentary based on some recent observations. Aqua Feeds: Formulation and Beyond, 1: 12-13.

Fjellheim, A. J., Klinkenberg, G., Skjermo, J., Aasen, I. M. and Vadstein, O. 2010. Selection of candidate probionts by two different screening strategies from Atlantic cod (Gadus morhua L.) larvae. Vet. Microbiol., 144: 153-159. doi: 10.1016/j.vetmic.2009.12.032.

Garriques, D. and Arevalo, G. 1995. An evaluation of the production and use of a live bacterial isolate to manipulate the microbial flora in the commercial production of Penaeus vannamei post-larvae in Ecuador. In: Browdy, C. L. and Hopkins, J. S. (Ed.), Swimming through troubled water. Proceedings of the Special Session on Shrimp Farming, Aquaculture'95. World Aquaculture Society, Baton Rouge, p. 53-59.

Kang, C. H., Kim, Y., Oh, S. J., Mok, J. S., Cho, M. H. and So, J. S. 2014. Antibiotic resistance of Vibrio harveyi isolated from seawater in Korea. Mar. Pollut. Bull., 86: 261-265. doi: 10.1016/j.marpolbul.2014.07.008.
Kathiravan, V. and Krishnani, K. K. 2013. Heterotrophic nitrifying and oxygen tolerant denitrifying bacteria from greenwater system of coastal aquaculture. Appl. Biochem. Biotechnol., 169: 1978-1992. doi: 10.1007/s12010-0130109-2.

Krishnani, K. K. 2010. Detection and diversity of nitrifying and denitrifying bacteria in coastal aquaculture. Aquaculture, 302: 57-70. DOI: 10.1016/j.aquaculture.2010.01.024.

Krishnani, K. K. and Kathiravan, V. 2010. Quantitative method for detecting ammonia oxidising bacteria in coastal aquaculture systems. Aquac. Res., 41: 1648-1657. doi. $\operatorname{org} / 10.1111 / \mathrm{j} .1365-2109.2010 .02535 . \mathrm{x}$.

Krishnani, K. K., Kathiravan, V., Natarajan, M., Kailasam, M. and Pillai, S. M. 2010. Diversity of sulfur oxidising bacteria in greenwater system of coastal aquaculture. Appl. Biochem. Biotechnol., 162: 1225-1237. doi: 10.1007/ s12010-009-8886-3.

Krishnani, K. K., Shekhar, M. S., Gopikrishna, G. and Gupta, B. P. 2009. Molecular biological characterisation and biostimulation of ammonia oxidising bacteria in brackishwater aquaculture. J. Environ. Sci. Health., Part A, 44: 1598-1608

Lachlan, H., Leigh, O. and Sandra, S. 1996. A selective and differential medium for Vibrio harveyi. Appl. Environ. Microbiol., 62(9): 3548-3550

Moreno, E., Parks, M., Pinnell, L. J., Tallman, J. J. and Tumer, J. W. 2017. Draft genome sequence of a Vibrio harveyi strain associated with vibriosis in Pacific white shrimp (Litopenaeus vannamei). Genome Announc., 5(7). pii: e01662-16. doi: 10.1128/genomeA.01662-16.

Moriarty, D. 1999. Disease control in shrimp aquaculture with probiotic bacteria. microbial biosystems: new frontiers. In: Bell, C., Brylinsky, M. and Johnson-Green, P. (Ed.), Proceedings of the $8^{\text {th }}$ International Symposium on Microbial Ecology, Atlantic Canada Society for Microbial Ecology, Halifax, Canada, p. 237-243.

Pan, X., Wu, T., Zhang, L., Song, Z., Tang, H. and Zhao, Z. 2008. In vitro evaluation on adherence and antimicrobial properties of a candidate probiotic Clostridium butyricum CB2 for farmed fish. J. Appl. Microbiol., 105: 1623-1629. doi.org/10.1111/j.1365-2672.2008.03885.x.

Sasser, M. 1990. Technical note 101: Bacterial identification by gas chromatographic analysis of fatty acids methyl esters (GC-FAME). Del: MIDI, Inc., North Newark, USA. 
Stalin, N. and Srinivasan, P. 2016. Molecular characterisation of antibiotic resistant Vibrio harveyi isolated from shrimp aquaculture environment in the south-east coast of India. Microb. Pathog., 97: 110-118. doi: 10.1016/j. micpath.2016.05.021.
Tamura, K., Dudley, J., Nei, M. and Kumar, S. 2007. MEGA4: Molecular Evolutionary Genetics Analysis (MEGA) software version 4.0. Mol. Biol. Evol., 24: 1596-1599. DOI: 10.1093/molbev/msm092. 